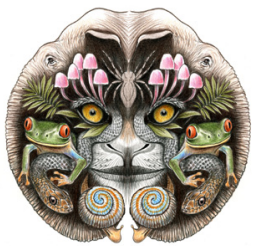

ISSN

Online 0974-7907

Print 0974-7893

\title{
TAXONOMY, DISTRIBUTION AND DIVERSITY OF FICUS PALMATA FORSSK. SUBSP. VIRGATA (ROXB.) BROWICZ (MORACEAE) IN INDIA
}

\author{
Rinkey Tiwari ${ }^{1}$, Jana Venkata Sudhakar ${ }^{2}$, Awadhesh Kumar Srivastava ${ }^{3}$, \\ Lal Babu Chaudhary ${ }^{4}$, Garimella Venkata Suryanarayana Murthy ${ }^{5} \&$ Anjala Durgapal ${ }^{6}$ \\ ${ }^{1,3,4}$ Plant Diversity, Systematics and Herbarium Division, CSIR-National Botanical Research Institute, \\ Rana Pratap Marg, Lucknow, Uttar Pradesh 226001, India \\ 2,5 Botanical Survey of India, Southern Regional Centre, Coimbatore, Tamil Nadu 641003, India \\ ${ }^{6}$ M.B. (P.G.) College, Haldwani, Nainital, Uttarakhand 263139, India \\ ${ }^{1}$ rinkeynbri@gmail.com, ${ }^{2}$ jvsbsi@yahoo.com, ${ }^{3}$ aanshul_84@rediffmail.com, \\ ${ }^{4} \mathrm{dr}$ Ibchaudhary@rediffmail.com (corresponding author), ${ }^{5}$ gvs.23.murthy@gmail.com, ${ }^{6}$ anjala.69@gmail.com
}

OPEN ACCESS

\begin{abstract}
The examination of a large number of herbarium specimens combined with field observations reveal that Ficus palmata Forssk. subsp. palmata does not occur in India. The Indian plants occurring in the wild from the north-west to the south belong to $F$. palmata Forssk. subsp. virgata (Roxb.) Browicz. The maximum concentration of the taxon lies in northern India extending up to about $2200 \mathrm{~m}$ altitude in the Himalaya. In southern India, the taxon is reported only in Andhra Pradesh. F. palmata subsp. virgata is notoriously variable in its entire range of distribution in almost all morphological characters. The variations are continuous and its two extreme forms, with entire leaves and lobed leaves, are connected with numerous intermediate forms. The taxon is closely allied to $F$. carica L., which is distributed from the Mediterranean region to Afghanistan and occurs only in cultivation in some parts of India. The paper also explains the relationship of the taxon with its closely allied species and provides a key to discriminate among them. In this paper, the taxon is described, illustrated with colour photographs and line drawings and provided with a distribution map.
\end{abstract}

Keywords: Distribution, diversity, Ficus palmata subsp. virgata, Identification, India, Moraceae.

DOI: http://dx.doi.org/10.11609/JoTT.03739.6172-85

Editor: Vijayasankar Raman, University of Mississippi, USA.

Date of publication: 26 August 2014 (online \& print)

Manuscript details: Ms \# 03739 | Received 24 July 2013 | Final received 25 July 2014 | Finally accepted 02 August 2014

Citation: Tiwari, R., J.V. Sudhakar, A.K. Srivastava, L.B. Chaudhary, G.V.S. Murthy \& A. Durgapal (2014). Taxonomy, distribution and diversity of Ficus palmata Forssk. subsp. virgata (Roxb.) Browicz (Moraceae) in India. Journal of Threatened Taxa 6(9): 6172-6185; http://dx.doi.org/10.11609/JoTT.03739.6172-85

Copyright: (C) Tiwari et al. 2014. Creative Commons Attribution 4.0 International License. JoTT allows unrestricted use of this article in any medium, reproduction and distribution by providing adequate credit to the authors and the source of publication.

Funding: Council of Scientific and Industrial Research, New Delhi, India (BSC-0106) \& Uttar Pradesh State Biodiversity Board, Lucknow, India (921/3-4-66).

Competing Interest: The authors declare no competing interests.

Author Contribution: RT - survey, collection, identification and writing manuscript; JVS - survey, collection, identification and phenological data; AKS - survey, collection and formatting; LBC - survey, collection, identification, structure of manuscript and overall management of the work; GVSM - provided guidelines and discussion on the subject; $A D$ - provided guidelines and discussion on the subject.

Author Details: MS. RINKEY TIWARI works on Ficus taxonomy; MR. JANA VENKATA SUDHAKAR works on Ficus taxonomy; MR. AWADHESH KUMAR SRIVASTAVA works on tree species of Uttar Pradesh; DR. LAL BABU CHAUDHARY works on angiosperm taxonomy since last 24 years on different aspects of taxonomy, presently working on tree species of Uttar Pradesh and Ficus taxonomy; DR. GARIMELLA VENKATA SURYANARAYANA MURTHY works on angiosperm taxonomy, palynology etc. since last 30 years; DR. ANJALA DURGAPAL works since last many years on different aspects of plants and guides PhD students.

Acknowledgements: The authors are thankful to the Directors of CSIR-National Botanical Research Institute, Lucknow and Botanical Survey of India, Kolkata for providing facilities. The in-charge of herbaria mentioned in the work is duly acknowledged for their kind permission for herbarium consultation. This work was carried out from the financial assistance received from CSIR, New Delhi under the project BSC-0106 and Uttar Pradesh State Biodiversity Board, Lucknow. 


\section{INTRODUCTION}

The genus Ficus L. (commonly known as 'figs') with ca. 735 species in the world is divided into six subgenera, 19 sections and 27 subsections (Berg \& Corner 2005). Although the genus has been studied at regional and global levels (Corner 1958, 1965, 1981; Berg 1989, 2003 , 2004 a,b; Kochummen 1998; Dixon 2003; Wu et al. 2003; Burrows \& Burrows 2003; Berg \& Corner 2005), the Indian figs have not been revised after King (1887$88,1888)$ till date while a large number of specimens have been added from different parts of India during the last 100 odd years. Recently, Chaudhary et al. (2012) published a checklist of Indian Ficus which consisted of 115 taxa (89 species and 26 infraspecific taxa). The present work is also an outcome of the revisionary study of the genus in India.

Ficus virgata Roxb. was described by W. Roxburgh in his Flora Indica in 1832 from Rohilkhand of Uttar Pradesh in India. He also described another species, $F$. caricoides Roxb., in the same work from Lucknow (Uttar Pradesh) and differentiated it from $F$. virgata chiefly based on the size of the plants. Later on, it was reduced as a synonym under quite variable species $F$. virgata by Brandis (1874). Subsequently, King (1888) merged these two species under F. palmata Forssk. However, there are disagreements among various workers regarding the correct identity and distribution of $F$. palmata and F. virgata since long. Browicz (1982) has pointed out that typical F. palmata (Image $1 \mathrm{~A}$ ) occurs only in eastern Africa and the southern Arabian Peninsula, and differs from $F$. virgata Roxb. in having leaves more elongated, acute or acuminate at apex and glabrescent or completely glabrous, whereas in F. virgata Roxb. the leaves are ovate, broadly ovate, elliptic or almost rounded, acute to rounded or truncate at apex and puberulous to densely tomentose on both the surfaces. He also observed that $F$. virgata Roxb. was distributed from Afghanistan to Nepal and treated it as a subspecies under F. palmata Forssk.

Following the above treatments, the Indian plants have been variously identified by various workers under different names (Table 1). A critical examination of the large numbers of the Indian materials (generally misidentified as either F. palmata or F. carica) in different herbaria reveals that the Indian plants belong to $F$. palmata Forssk. subsp. virgata (Roxb.) Browicz, which exhibits tremendous variations in habit, habitat, leaf, fig, flower, etc. These variations cause great difficulties in identification and delimitation of the species. The variations are so pronounced that collections from different areas or within an area appear to be different due to variable features. Sometimes the form with entire leaves is described as F. palmata whereas the form with lobed leaves is described as F. carica, while all variations can be seen on the same plant in different areas. Since these variations are continuous with numerous intermediate forms, delimiting infraspecific taxa is not possible. The dioecious nature of plants, which are similar in their gross morphology, makes it even more difficult to delineate.

Sometimes Ficus palmata subsp. virgata is also confused with its closely allied species $F$. carica (Image 1B), known only in cultivation in some parts of India for its fig/fruit commonly known as 'anjeer' (Hindi). F. carica is a native from the Mediterranean region to Afghanistan and differs from F. palmata (including F. palmata subsp. virgata) in degree of pubescence and thickness of young stems, colour and pubescence of tepals and size of figs. In $F$. carica, the twigs are glabrous or glabrescent and stouter, figs more than $2 \mathrm{~cm}$ in dia. and tepals often glabrous or rarely glabrescent and white to pink while in F. palmata the twigs are tomentose and slender, figs up to $2 \mathrm{~cm}$ in dia. and tepals puberuolous and white (Corner 1965). In addition, the figs of F. palmata are hard and unpalatable, whereas the figs of $F$. carica are sweet, tasty and edible when ripe (Roxburgh 1832). Although these two species are treated separately till date, doubts have been raised by many other workers about the separate identity of the two species. King (1887-88), for example, has also pointed out that $F$. palmata may be a form of F. carica. In 'Figweb' (2004-2013), it has also been stated that both the species are probably conspecific. Molecular and chemical studies of this complex group may help resolve the confusion.

In view of the above, the main purpose of the present work is to (i) reevaluate the status of $F$. palmata subsp. virgata in India, (ii) record the range of variations, and (iii) provide its updated distribution status in India.

The raw figs of $F$. palmata subsp. virgata are used as vegetable and ripened figs as fruit generally by tribals and local people in hilly and forest areas (Parmar \& Kaushal 1982). Figs are demulcent, laxative and used in diseases of the lungs and bladder (Kirtikar \& Basu 2001). The twigs are used as fodder. The latex is said to be employed in curdling of milk (Maheswari 1963).

\section{MATERIALS AND METHODS}

This study is based on the examinations of about 300 herbarium specimens housed at BLAT, BSA, BSD, 

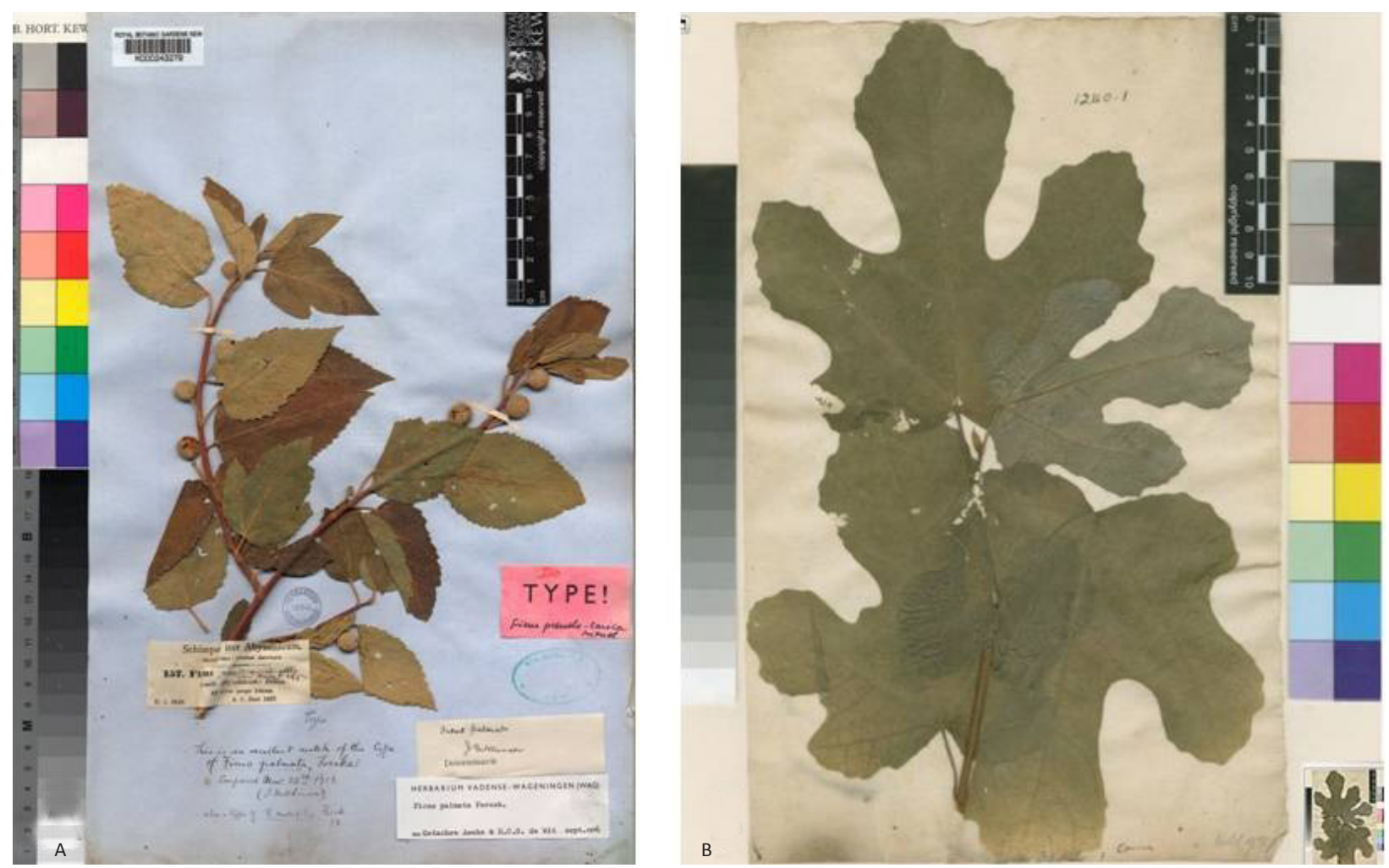

Image 1. A - Ficus palmata subsp. palmata; B - Ficus carica.

Table 1. Treatment of Ficus palmata Forssk. subsp. virgata (Roxb.) Browicz in Indian works

\begin{tabular}{|l|l|}
\hline \multicolumn{1}{|c|}{ Name used in the publication } & \multicolumn{1}{c|}{ Authors } \\
\hline & $\begin{array}{l}\text { King 1888; Collett 1902; Brandis 1906; Duthie 1915; Bamber 1916; Parker 1918; Haines 1924; Gamble 1921; Osmaston } \\
\text { 1927; Mooney 1950; Maheshwari 1963; Nair 1977; Sharma \& Kachroo 1981; Chowdhary \& Wadhwa 1984; Verma et al. } \\
\text { Ficus palmata Forssk. }\end{array}$ \\
$\begin{array}{l}\text { 1985; Naithani 1985; Singh 1986; Sharma 1990; Roy et al. 1992; Saxena \& Brahmam 1995; Hajra \& Balodi 1995; Pullaiah \& } \\
\text { Maulali 1997; Khanna \& Uniyal 1997; Bhattacharyya \& Sarkar 1998; Swami \& Gupta 1998; Dhaliwal \& Sharma 1999; Singh } \\
\text { \& Sharma 1999; Gaur 1999; Khanna et al. 1999; Singh \& Rawat 2000; Singh et al. 2001 a, b; Sharma 2002; Singh \& Prakash } \\
\text { 2002; Rana et al. 2003; Rao \& Kumari 2008. }\end{array}$ \\
\hline Ficus virgata Roxb. & Roxburgh 1832; Stewart \& Brandis 1874. \\
\hline Ficus caricoides Roxb. & Roxburgh 1832; Stewart 1869. \\
\hline $\begin{array}{l}\text { F. palmata Forsk. subsp. virgata } \\
\text { (Roxb.) Browicz }\end{array}$ & Browicz 1982; Singh 1983; Parmar et al. 1991; Kumar 2001; Kumar et al. 2011; Chaudhary et al. 2012. \\
\hline Ficus carica L. & $\begin{array}{l}\text { Stewart 1869; Stewart \& Brandis 1874; Brandis 1906; Maheshwari 1963; Srivastava 1976; Shah 1978; Sharma \& Kachroo } \\
\text { 1981; Sharma \& Dhakre 1995; Swami \& Gupta 1998. }\end{array}$ \\
\hline
\end{tabular}

BSI, CAL, DD, LWG, MH, SKU as well as observations of a large number of plants in the wild in different parts of the country. The micro-morphological characters have been observed under a Stereo Zoom Microscope (Leica, Germany). Line diagrams of habit and parts of the plants have been made to show the range of variations. Pictures of habit and different parts of the plant have also been included. The distribution of the species in India has been shown on the map based on the collection locations of the specimens examined. No specimens from Bihar and Gujarat were found in any of the herbaria mentioned above. However, what is mapped here is based on the authors' field observations as well as reports by Haines (1924), Shah (1978), Singh (1986), Pandey \& Padhye (2000), and Singh et al. (2001b).

\section{RESULTS}

\section{Morphological Diversity}

Habit: Ficus palmata subsp. virgata (Figs. 1a-m \& Images 2a-f) occurs in two distinct forms: bushy shrubs and small or medium-sized trees. Sometimes the plants 
have a single weak stem, giving an appearance of a large herb. The bushy form of the plant is sometimes found hanging on the mountain slopes. Both shrubby and tree forms branch profusely. In the tree form, the leaves are comparatively smaller than that of the shrubs. The girth of the tree trunk ranges from $30-60 \mathrm{~cm}$ in diam.

Indumentum: The hairs distinctly differ from plant to plant and population to population within the species. They are quite dense on young twigs, stipules and leaves, but become sparse at maturity. Due to the presence of puberulous or scabrous types of hairs, the upper surfaces of the leaves and receptacles are rough to touch while the lower surfaces are soft, cottony and hairy.

Leaves: The leaves show tremendous variations in lamina shape, size, base, margins and lobation between plants or on the same plant. The leaves of bushy or shrubby forms are larger (up to $27 \times 24 \mathrm{~cm}$ ) than the leaves of the tree form. The leaves show distinct dimorphism in the taxon. Generally, the leaves are unlobed, but distinctly 3-5-lobed leaves are also not rare. In bushy and shrubby forms, the leaves are usually entire, but sometimes, in the lower portion of plants, the lobed and entire leaves are intermixed. On trees, both types of leaves are either found on the same branch or occasionally on separate branches. The leaves are ovate to broadly ovate with acute tip or sometimes almost rounded with truncate or rounded apex. The base of the leaves also vary from cuneate to obtuse or cordate. The leaf-margin, which is considered one of the important taxonomic characters, also differs from plant to plant from subdentate to dentate to distinctly serrate Fig. 2 .

Stipules: The stipules are not much variable. They are caducous and leave scars on twigs. Generally, they are greenish throughout, but sometimes the tip portion becomes reddish (Image $2 \mathrm{~B}$ ).

Bracts: The bracts are associated with syconium or fig. The number of basal bracts varies from $2-4$. The basal bracts are present at the base of the fig body when figs are without stipe or they may occur at the base of the stipe in stipitate figs. The margins of basal bracts are entire or slightly undulate. The apical bracts are found in many rows around the ostiole. The outermost row of 3-6 bracts is compactly arranged whereas the bracts in inner rows are loosely arranged. These bracts show variations in the colour as well as their opening nature. Since $F$. palmata subsp. virgata is dioecious the male and female figs are located on different plants which are almost indistinguishable through vegetative characters. However, in the male figs the apical bracts protrude outwardly during the time of pollination to allow the insects to enter into the fig. Sometimes the outward projection of the bracts is so pronounced that it makes a clear ostiolar opening through which the stamens present near the ostiole also come outside the fig which may help in segregation of male and female plants and figs. While in the female figs the apical bracts do not protrude outwardly and remain flat. The colour of the apical bracts distinctly varies from faintly to prominently red to pink or sometimes only green with a tinge of red. Image 3.

Figs: Fig is one of the important taxonomic characters in the genus Ficus. Traits like their position, number per axil, the presence or absence of peduncle and stipe, shape and size, colour, the presence or absence of hairs and bracts on fig body etc., are frequently used to distinguish the taxa at different levels. However, in the present case the figs are considerably variable in their number per axil, peduncle and stipe length, size and shape, colour etc. In the candidate taxon the figs are axillary and generally solitary. But paired figs are also seen frequently on different plants or on the same plant. As far as the length of stipe and peduncle of fig is concerned, they drastically vary from plant to plant and sometimes they become so reduced that the figs appear almost sessile and give the false appearance of a different taxon. The figs are initially green which turn dark purple to almost black after ripening (Image 2E-F).

Flower: In this taxon five types of flowers are seen: male, female, gall, pseudo-hermaphrodite and neuter. All these types of flowers do not occur within the same syconium as the taxon is dioecious. The female and neuter flowers are present in a single syconium known as a female syconium which grows on female plants. The male, gall and pseudo-hermaphrodite flowers occur within a same syconium known as male syconium which grows on male plants Fig. 1.

Male flowers in syconium are arranged in a bunch near ostiole as well as scattered inside the whole syconium along with gall flowers. In male flowers the number of tepals generally varies from 4-6 which are almost free except basal portion. Occasionally, the tepals are three, but they are almost divided nearly to the base or above the base so that they look like six in number. Irregular lobbing of tepals is also frequently seen. Similarly, the number of stamen also varies from 3-6. The gall flowers which occur throughout the syconium except the ostiolar region have tepals which are same as that of male flowers but has one ovary with a short style. The wasp completes its life cycle in the ovary of the gall flower so seeds are not formed. A pseudo-hermaphrodite flower contains three tepals, 

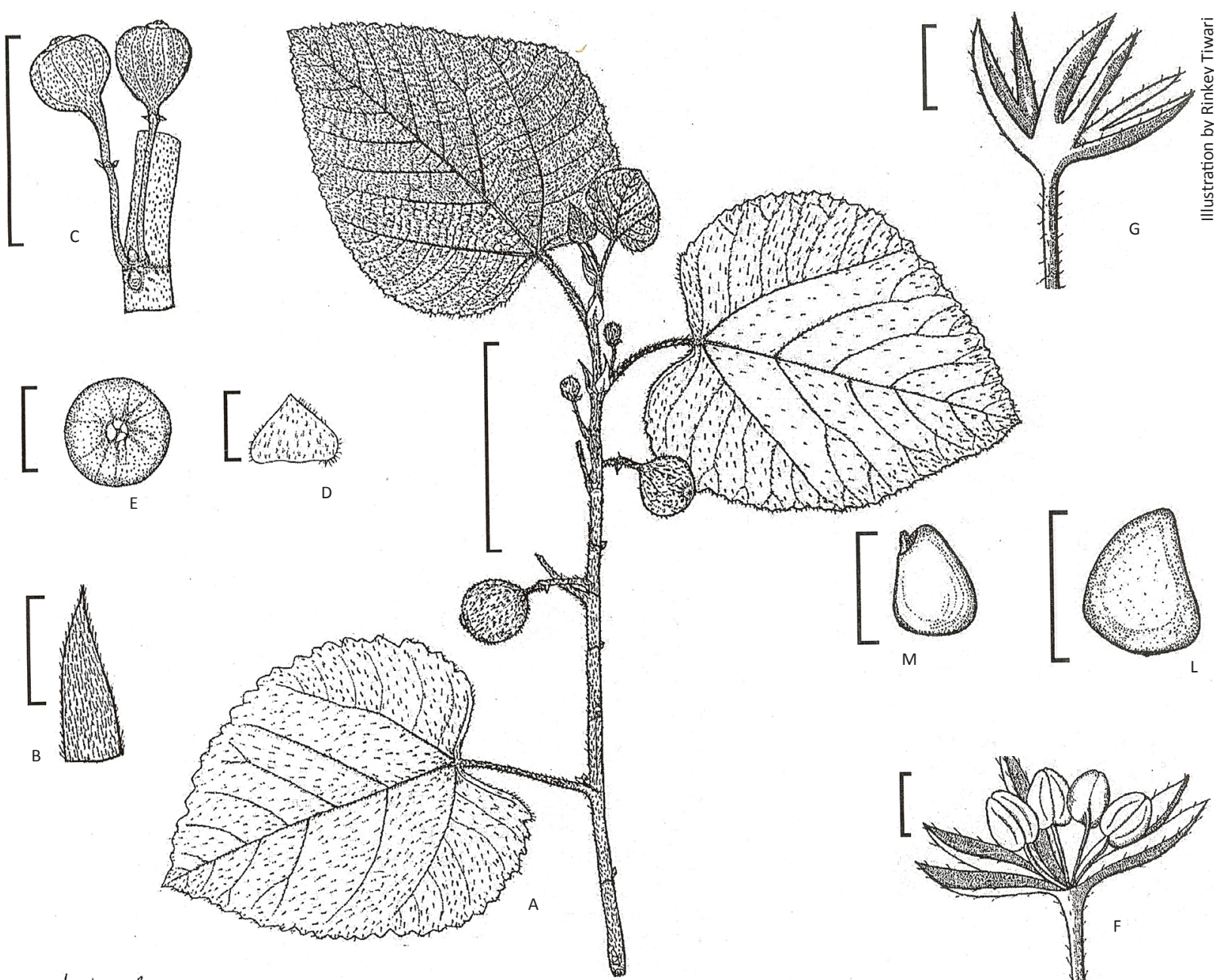

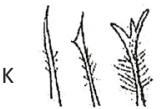
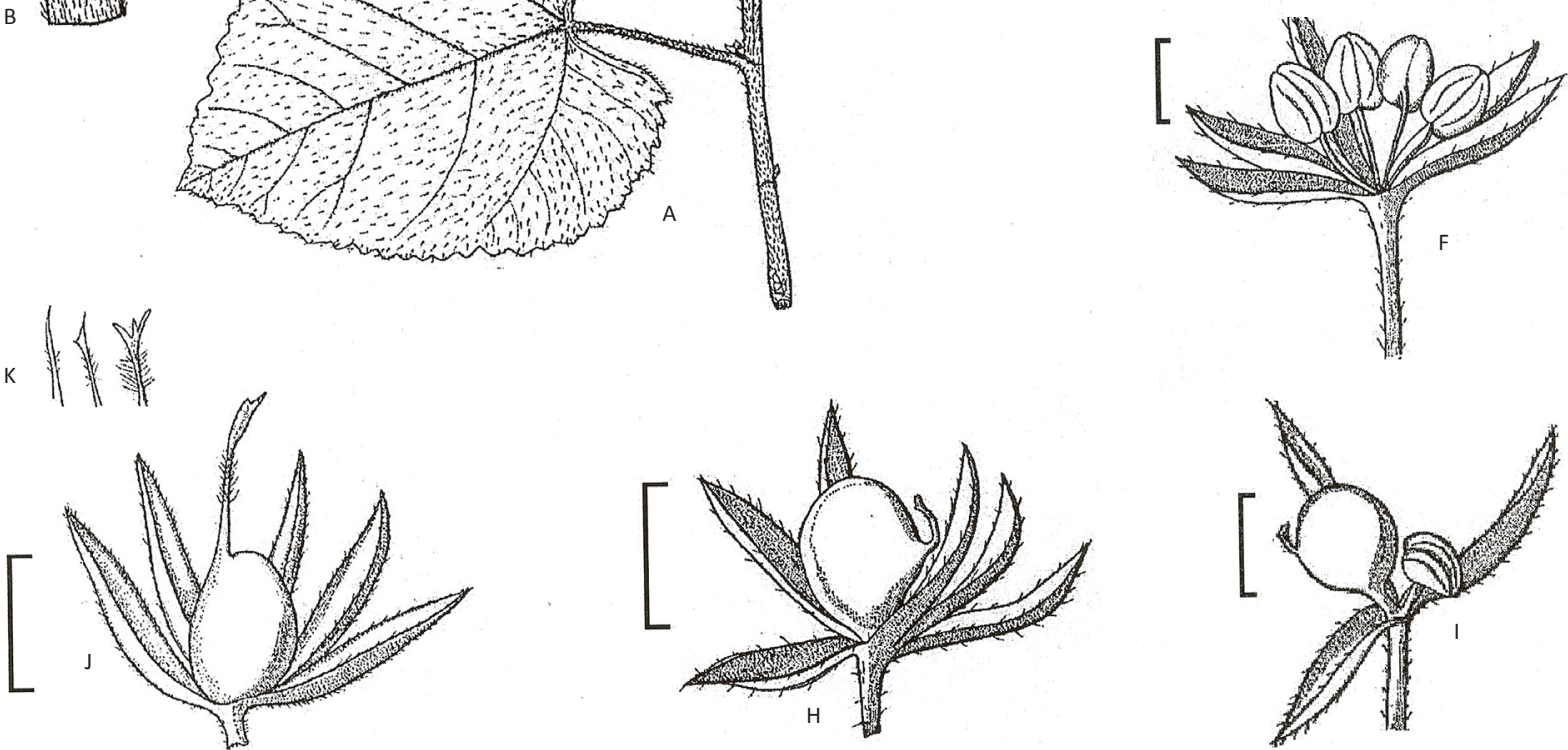

Figure 1. Ficus palmata subsp. virgata.

A - habit; B - stipule. C - part of stem with figs; D - basal bract; E - apical portion of fig; F - male flower; G - male flower (stamens removed); H - gall flower; I - pseudo-hermaphrodite flower; J - female flower. K - variation in stigma. (A: from K. N. Nair 250799, B: from Tiwari \& Chaudhary 264508, C: from Chaudhary \& Bajpai 259301, D, E \& J: from Tiwari \& Chaudhary 264509, F-H: from K. U. Garad KUG 548, I: from Kumar \& Bajpai 252270, K (left to right): from Tiwari \& Chaudhary 264508, 264509 \& 264501, L \& M: from Chaudhary \& Bajpai 259304) Scale: $A \& C=5 \mathrm{~cm}, B=1 \mathrm{~cm}, D=2 \mathrm{~mm}, E=2 \mathrm{~cm}, F-M=1 \mathrm{~mm}$.

one stamen and a ovary, which is occupied by a wasp as in the case of gall flowers.

Female flowers are present throughout the inside of the female syconia. They are mostly sessile but sometimes pedicellate. In this case the number of tepals varies from 4-5. Like the male flowers a very irregular lobing in tepals has been noticed. Style is subterminal to lateral and comparatively longer than gall flowers. Stigma is usually bifid, however, linear, trifid or indistinctly bifid conditions have also been observed. 


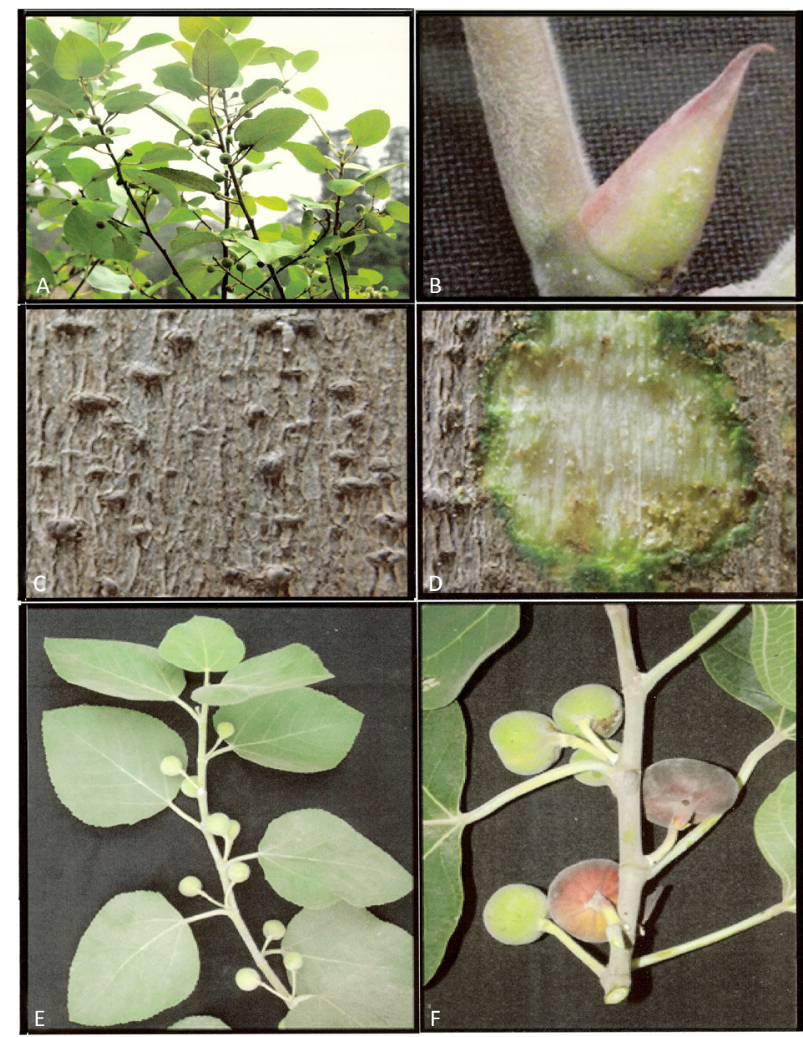

Image 2. Ficus palmata subsp. virgata.

A - habit; B - stipule; C - stem bark; D - Blaze; E - twig showing arrangement of leaves and figs; $F$ - twig bearing mature figs. (C) Rinkey Tiwari \& Awadhesh K. Srivastava

The length of the arms of stigma also varies considerably among different flowers. They may be either equal to each other or unequal. The color of the stigma varies from light to dark orange. Neuter flowers have reduced tepals without pistil and stamen, or sometimes with a staminode.

\section{Distribution Pattern}

Ficus palmata subsp. virgata is commonly distributed in northwestern India from the plains to an altitude of $2200 \mathrm{~m}$ in the Himalayas with a maximum concentration in Himachal Pradesh, Punjab, Rajasthan, Uttarakhand and Uttar Pradesh. Singh (1986) has observed that the taxon is very common in Patna (Bihar). Mooney (1950) has mentioned that the taxon is seemingly rare in Odisha. The report from West Bengal is only based on garden grown plants as the taxon has not been reported earlier (Prain 1903). So far the species has not been reported from the north-east region, which is considered to be one of the richest regions for Ficus in India (Chaudhary et al. 2012), probably due to the high humidity and rain fall prevailing in the region. The frequency of occurrence of the species from the north

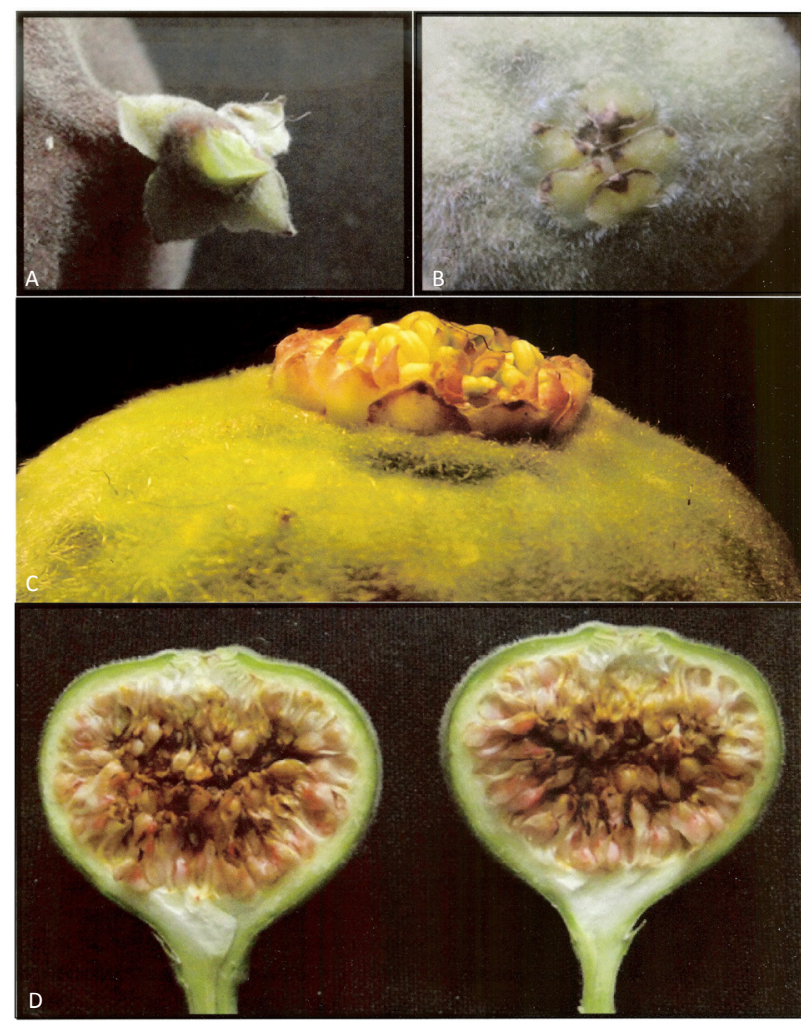

Image 3. Ficus palmata subsp. virgata.

A - Basal bract; B - Apical bracts; C - Apical portion of male fig showing protruded anthers; D - Vertical section of a male fig. (C) Rinkey Tiwari \& Awadhesh K. Srivastava

to south is distinctly diminishing. In the southern region, the species is so far known only from Visakhapatnam District of Andhra Pradesh. Matthew (1999) reported the species from the Palni Hills in Tamil Nadu based on a cultivated plant, which on critical examination turned out to be $F$. carica. Similarly, its report from Kerala by Kader (2009) is erroneous as it is based on misidentified specimens of Broussonetia papyrifera (L.) L'H'er. ex Vent.

\section{Key to the taxa}

1a. Twigs glabrous or glabrescent, stouter; figs more than $2 \mathrm{~cm}$ in diam.; tepals white to pink, glabrous or rarely glabrescent.

F. carica 1b. Twigs tomentose, slender; figs up to $2 \mathrm{~cm}$ in diam.; tepals white, puberulous. 2 2a. Leaves more elongate, acute or acuminate at apex, glabrescent to glabrous

..F. palmata subsp. palmata

$2 b$. Leaves ovate, broadly ovate, elliptic or almost rounded, acute to rounded or truncate at apex, puberulous to densely tomentose......

F. palmata subsp. virgata 

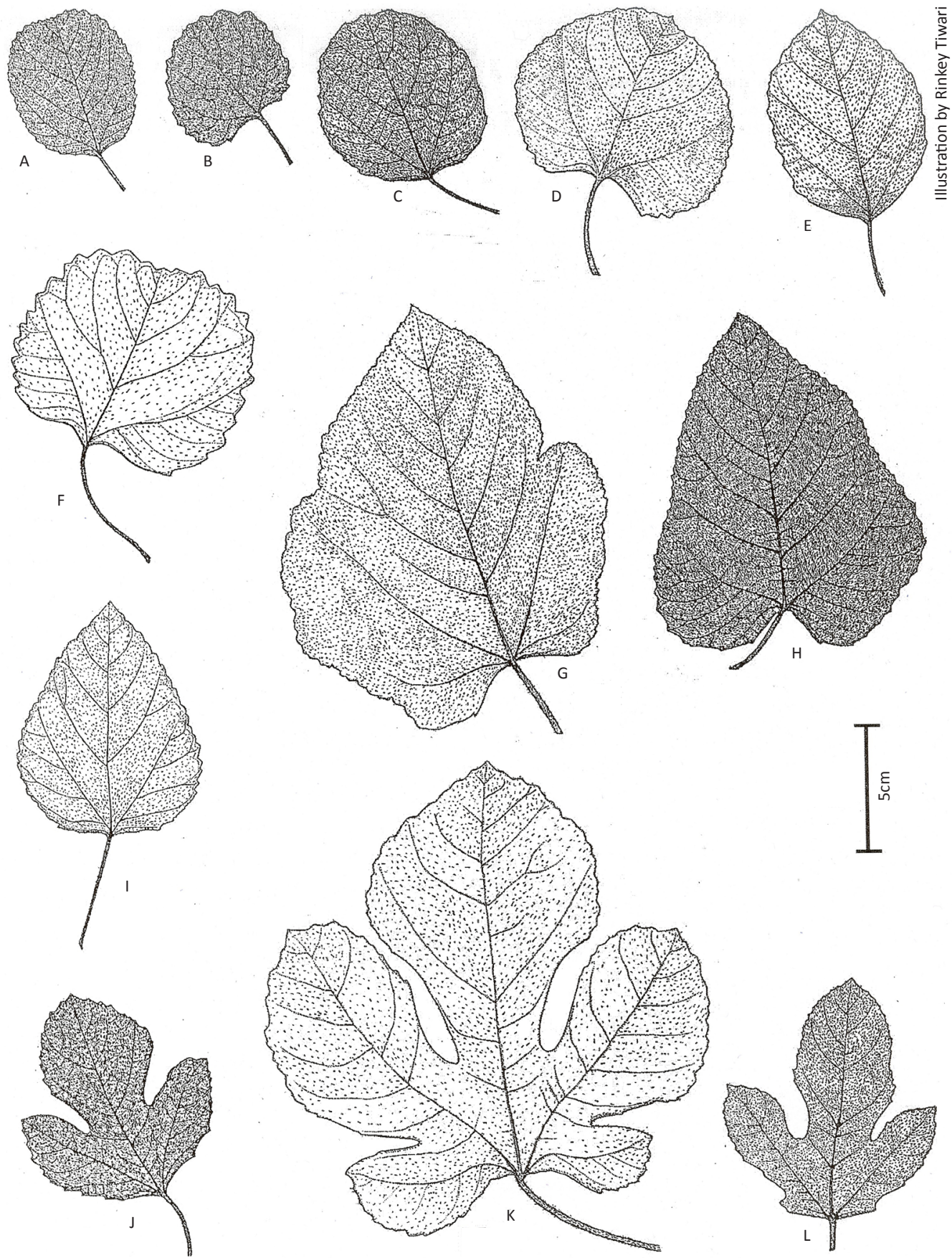

Figure 2: Ficus palmata subsp. virgata. Variations in leaf morphology (A - based on specimens S.D. Maliya 225287; B - K.N. Nair 250799; C \& E - Kumar \& Bajpai 252270; D - L.B. Chaudhary et al. 250294; F - Singh \& Kumar EBH 10024; G - Chaudhary \& Tiwari 250375;

H - L.B. Chaudhary 250252; I - Rana \& Bajpai 218849; J - J.G. Srivastava et al. 58493; K - Chaudhary \& Tiwari 250375; L - based on K. Kumar EBH 9821) (A, B, C, H, J, L: lower surface; D, E, F, G, I, K: upper surface).

\section{Taxonomic Treatment}

Ficus palmata Forssk. subsp. virgata (Roxb.) Browicz in Rechinger, Fl. Iranica 153. 12, t. 6. 1982; . Singh, Fl. Banswara 216. 1983; Parmar in Shetty \& Singh, Fl. Rajasthan 803. 1991; Kumar, Fl. Haryana 355. 2001;
Kumar et al., American J. PI. Sci. 2: 84. 2011; Chaudhary et al., Taiwania 57 (2): 194. 2012.

F. virgata Roxb., Fl. Ind. 3: 530. 1832. Type: Rohilkhand ('Rohilcund'), India. Roxburgh described from wild specimens.

F. caricoides Roxb., Fl. Ind. 3: 529. 1832. Type: 
Cultivated specimen sent to Botanical Garden, Calcutta sent by General Martin from Lucknow.

F. palmata auct pl.: King in Ann. Bot. Gard. Calcutta 1: 146, t. 185.1888 p. p. (excl. syn. F. pseudo-sycomorus Decne) \& in Hook. f., Fl. Brit. India 5: 530. 1888 p. p. (excl. syn. F. pseudo-sycomorus Decne); Collett, FI. Siml. 460, f. 148. 1902; Brandis, Indian Trees 607. 1906; Corner in Gard. Bull. Singapore 21 (1): 36. 1965; Nair in Rec. Bot. Surv. India 21 (1): 244. 1978.

Vernacular names: Gujarati: Pepri, Anjir; Hindi: Anjiri, Bedu, Jangli Anjir, Khemri, Kaimbar, Khat Guleri, Patguleri, Kembu; Punjabi: Phagwara, Jamir; Telugu: Mansimedi, Manjimedi (Kirtikar \& Basu 2001).

Small bushy shrubs to trees, 1-8 $\mathrm{m}$ tall, with white milky sap, dioecious; stems ca. $60 \mathrm{~cm}$ in dia., twigs solid with soft white pith, cylindrical, villous to tomentose when young; bark whitish to greyish with scattered lenticels, blaze yellowish-white. Stipules 1.5-2×0.5-1 $\mathrm{cm}$, caducous, narrowly triangular, truncate at base, entire along margins, acute to acuminate at apex, glabrous above, puberulous beneath. Leaves alternate, simple; petioles 2-12 cm long, puberulous; lamina variable in shape and size, $3-27 \times 2.5-24 \mathrm{~cm}$, entire or deeply 3-5-lobed, ovate, broadly ovate, elliptic, almost rounded, caudate or reniform; base cuneate, cordate, subcordate, rounded, obtuse or truncate, margins serrate, subdentate, dentate or undulate; apex acute, obtuse-apiculate, rounded or truncate, rough in texture and sparsely puberulous to moderately scabrous or velutinous on upper surface, coriaceous and moderately to densely tomentose on lower surface, hairy along veins and veinlets, basal veins $2-4(-6)$, lateral veins 3-9 pairs. Figs/syconia (male and female both) axillary, solitary or paired, pedunculate, male and female present on separate plants; peduncles $0.5-4.2 \mathrm{~cm}$ long, erect, villous or puberulous; basal bracts (2-) $3(-4)$, ca. $3 \times 3 \mathrm{~mm}$, triangular, truncate at base, entire to minutely undulate and sometimes purple along margins, acute to obtuse at apex, puberulous at both surfaces; receptacle (fig body) $1-2 \times 1.5-2 \mathrm{~cm}$, obovate or globular, green when young, purple when ripe, lenticellate throughout the body, puberulous to tomentose, sessile or with up to $1 \mathrm{~cm}$ long puberulous or tomentose stipe; apical bracts present in many rows, ca. $2 \times 2 \mathrm{~mm}$, triangular, truncate at base, entire and pinkish along margins, hairy above, glabrous beneath. Male receptacles consist of male, gall and sometimes pseudo-hermaphrodite flowers; male flower numerous, densely present in the upper part of the receptacle near ostiole, sparsely all over, 4-5 mm long; pedicels 2-3 mm long; tepals ca. $2 \mathrm{~mm}$ long, hyaline, united at base, 5 or 6 -lobed, sometimes only 3 -lobed which further divide into two, boat-shaped, acute at apex, thinly hairy above, glabrous beneath; stamens 3-6, filament 0.5-1.0 mm long, glabrous, anthers dorsifixed, bilobed; gall flowers present throughout inside fig, ca. 4 $\mathrm{mm}$ long; pedicels 1-2.5 mm long; tepals 4-5, 1.5-2.0 $\mathrm{mm}$ long, similar to male flowers; ovary 1-1.2 mm, globular, style short, laterally attached, stigma orange, mostly linear bifid; pseudo-hermaphrodite flowers 4-5 mm long; pedicels 3-4 mm long, hyaline, hairy; tepals ca. 3, sometimes irregularly divided, lanceolate, cuneate at base, entire along margins, acute at apex, hyaline, hairy above; stamen 1 , filament $0.5 \mathrm{~mm}$ long, anther ca. $1 \mathrm{~mm}$ long; ovary ca. $1.0 \mathrm{~mm}$. long, globular, style and stigma reduced. Female receptacles consist of female and neuter flowers; female flowers present throughout inside fig body, 3-7 $\mathrm{mm}$ long, sessile to 1.0-1.5 mm long pedicelled; tepals $4-5,1-1.5 \mathrm{~mm}$ long, lanceolate, sometimes one of them may be bilobed, cuneate at base, entire and hairy along margins, acute to acuminate to rounded at apex, minutely hairy above, glabrous beneath; ovary 1.0-1.5x0.8-1.0 mm long, rounded to ovoid, sessile, style $2-2.5 \mathrm{~mm}$ long, terminal or subterminal to lateral, stigma linear to bifid or trifid, lobes $0.5 \mathrm{~mm}$ long, unequal. Achenes ovoid or triangular, 1.2-1.5x1.0-1.2 mm, glabrous, olive-yellow.

Distribution: India (plains to ca. $2200 \mathrm{~m}$ in the Himalayas: Bihar, Chhattisgarh, Gujarat, Haryana, Himachal Pradesh, Jammu and Kashmir, Madhya Pradesh, Maharashtra, Odisha, Punjab, Rajasthan, Uttarakhand, Uttar Pradesh, West Bengal, and Andhra Pradesh). Sometimes planted in gardens. (Fig. 3). Afghanistan, Nepal, Pakistan.

Phenology: Formation of figs almost throughout the year.

Habitat/Ecology: Ficus palmata subsp. virgata grows in various kinds of habitats from plains to hills, usually in wastelands along railway tracks and roadsides, near agricultural fields and human habitations and also in forest areas, either in rocky-gravelly soils or in clayloamy soils. It is also frequently planted in gardens and found growing on walls of old, abandoned buildings.

Specimens examined: Andhra Pradesh: Visakhapatnam District: 08.vi.1952, by the side of the stream, Araku Valley, coll. D.D. Sunderaraj 95905 (MH); 28.viii.1960, Forest near Sunkarimettta, $1075 \mathrm{~m}$, coll. N.P. Balakrishnan 10901 (MH); 17.v.1964, From first bungalow towards Araku Valley, 1200m, coll. G.V. Subba Rao 19665 (MH); 10.viii.1973, near Bispuram, 1150 m, coll. G.V. Subba Rao (MH); 21.iv.1995, Galikonda, coll. K. Jayamma \& S. Sandhya Rani 12585 (SKU); 03.x.2011, Vanjari Village near well, Chintapally to Paderu via 


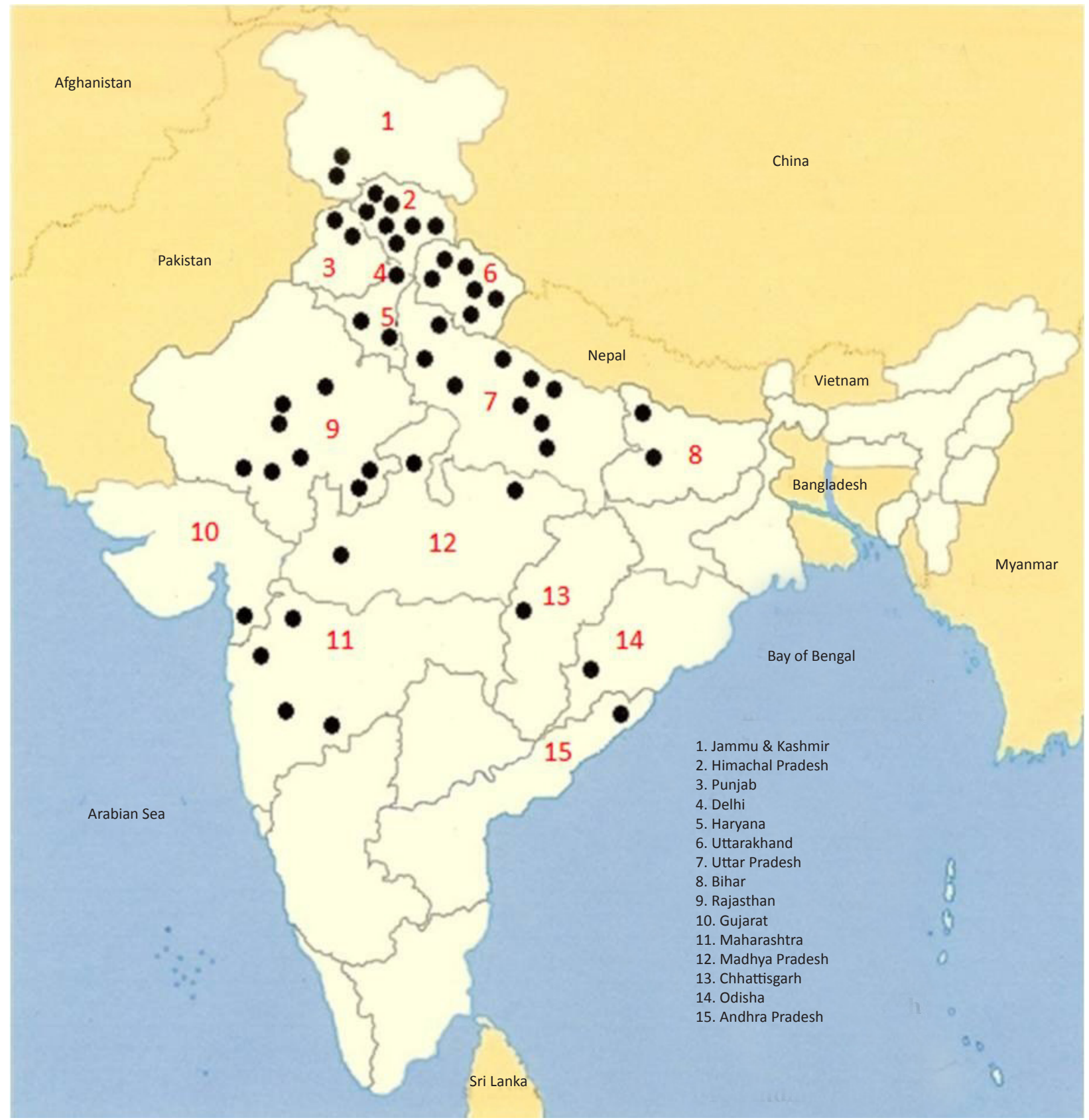

Figure 3. Distribution of Ficus palmata subsp. virgata in India.

Sanjeevani, 1000m, coll. J.V. Sudhakar 126766 (MH); 03.x.2011, near Kulapadu Village, 1000m, coll. J.V. Sudhakar 126767 (MH). Chhattisgarh: Rudraprayag District: 20.iv.1963, Rudraprayag, coll. C.L. Malhotra 26813 (BSD); 1913, Ramnagar Div., Aduala Range, 792m, coll. H. Singh 7844 (DD); May 1940, Sanna, 854m, coll. H.F. Mooney 1329 (DD); Raipur District: 14.x.1874, 914m, coll. C.B. Clarke 23762 (CAL); Raigarh District: Oct.1984, Gumharia, coll. R.P. Dwivedi 3596 (LWG). Delhi: New Delhi: 20.x.2012, IARI, A.Pramanik 264524,
264525 (LWG). Haryana: Hisar District: 12.ii.1963, Hansi, coll. N.C. Nair 25888 (BSD); 07.iv.1965, Bhivani, coll. N.C. Nair 34583 (BSD); Panchkula District: 21.xii.2011, Morni Hills, Tikkar Lake, coll. A. Pramanik 264529 (LWG); Yamuna Nagar: 21.iv.1986, on Yamuna River bank, coll. J.P. Sharma 77934 (BSD); Sirsa District: 29.iv.1962, Kera, coll. V.J. Nair 21552 (BSD). Himachal Pradesh: Bankhandi District: 12.iv.1972, coll. O.P. Misra 47101 (BSD); Chamba District: 03.vii.1974, along Ravi River, Rakh, coll. B.M. Wadhwa 49487 (BSD); 11.v.1957, 1100m, coll. 
M.A. Rau \& Y.K. Sarin 2593 (BSD); 21.vi.1864, Brandis s.n. (CAL); 12.x.1874, 14.x.1874, Chamba, 914m, coll. C.B. Clarke 23703B, 23762 (CAL); 22.viii.1898, Chamba, 1,219m, Kulhal, coll. G.A. Gammei 18187 (DD); 13. vii.1963, Dalhousie, $2000 m$, coll. C.L. Malhotra \& V.J. Nair 27339 (BSD); 14.vii.1963, Dalhausie, 2000m, coll. C.L. Malhotra \& V.J. Nair 27400 (BSD); Hamirpur District: 12.viii.1977, East of Bijhari, coll. M.V. Viswanathan 61623 (BSD); Kangra District: July 1998, Kangra Valley, Dharamkot, Kaushal Kumar EBH 9821 (LWG); June 1999, Dharamshala, Kangra Vellay, coll. K.K. Singh \& K. Kumar EBH 10024 (LWG); 26.vii.1963, Jawalamukhi, coll. S.K. Malhotra 29137 (BSD). Kinnaur District: 29.v.1962, Sholtu, 1500m, coll. N.C. Nair 22113 (BSD); 31.v.1972, Kilba, 2275m, coll. K.P. Janardhanan 47549 (BSD); 15. vi.1972, Sholtu, $1683 \mathrm{~m}$, coll. K.P. Janardhanan 48417 (BSD); 25.viii.1973, Karcham, Baspa Valley, coll. K.P. Janardhanan 52832 (CAL); Kullu District: 25.v.1959, Naggar, Kullu Valley, coll. J.G. Srivastava et al. (LWG); 08.v.1914, Beas Valley, 1,219m, R.S. Tromp 8131 (DD); 16.vii.1972, Manali, $1800 \mathrm{~m}$, coll. U.C. Bhattacharya 48552 (BSD); 15.vii.1972, Manali, 1800m, coll. U.C. Bhattacharyya 48501 (BSD); 03.viii.2012, Near Manali Town, 1869m, coll. L.B. Chaudhary \& O. Bajpai 259303 (LWG); 03.viii.2012, Near Manali town, 1869m, $32^{\circ} 14.128^{\prime} \mathrm{N} \& 77^{0} 11.185^{\prime} \mathrm{E}$, coll. L.B. Chaudhary \& O. Bajpai 259301 (LWG); 03.viii.2012, Near Manali town, $1869 \mathrm{~m}, 32^{\circ} 14.128^{\prime} \mathrm{N} \& 77^{\circ} 11.185^{\prime} \mathrm{E}$, L.B. Chaudhary \& O. Bajpai 259302 (LWG); 03.viii.2012, 5km before Manali Town, $1794 \mathrm{~m}, 32^{\circ} 13.111^{\prime} \mathrm{N} \& 7^{0} 11.576^{\prime} \mathrm{E}$, coll. L.B. Chaudhary \& O. Bajpai 259304 (LWG); 18.x.1984, Kasol, coll. P.K. Hajra 76903 (BSD); Palampur: September 1997, Bandla, coll. K.K. Singh EBH 9622 (LWG); Mandi District: 18.v.1959, on Kullu Road, coll. J.G. Srivastava et al. 58493 (LWG); 26.viii.1977, 760m, coll. S.K. Murti \& R. Prasad 62100 (BSD); 12vi.1958, 1000m, coll. M.A. Rau 5691 (BSD); Shimla Dsitrict: 23.ix.1977, Gowai, 1,829m, Gamble 5316c (DD); 30.v.1986, Ghanahatti Forest, P.C. Pant 80854 (BSD); 09.viii.2012, 1km after Tapra towards Shimla, $31^{\circ} 32.120^{\prime} \mathrm{N} \& 7^{\circ} 02.561^{\prime} \mathrm{E}$, coll. L.B. Chaudhary 259354 (LWG); 20.ix.1877, 1,829m, coll. J.S. Gamble 5316 (CAL); 25.vi.1903, Iskayli, 19069 (CAL); 16.v.1954, Jako Peak, coll. R. Singh 7251 (LWG); 03.vi.1954, on the way of Anandale, coll. R. Singh 12840 (LWG); 10.ix.1974, Sarhan, coll. J.N. Vohra 54360 (BSD); 28.viii.1963, Jeori, Bashahr, 1400m, coll. N.C. Nair 30006 (BSD); 24.v.1962, Jeori, 1450m, coll. N.C. Nair 21807 (BSD); 13.vi.1962, Jeori, 1475m, coll. N.C. Nair 22623 (BSD); Sirmour District: 12.ix.1974, Rajgarh on road to Deedhan, 1,524m, coll. J.N. Vohra 54391 (BSD); Una District: 18. vii.1977, near the bridge on Una-Hoshiyarpur Road, coll.
B.P. Uniyal 61099 (BSD); Solan District: 26.v.1986, Khari, Subathu, coll. P.C. Pant 80774 (BSD); 22.v.1986, Kundru, coll. P.C. Pant 80668 (BSD); 12.iv.1972, coll. O.P. Misra 45897 (BSD). Jammu and Kashmir: Doda District: 25. viii.1958, Tringala, Batote, 1,524m, coll. D. Thapliyal 26257 (DD); 16.viii.1962,Thathri, 1830m, coll. B.M. Wadhwa \& J.N. Vohra 368 (CAL); 30.viii.1962, Thathri, 915m, coll. B.M. Wadhwa \& J.N. Vohra 772 (CAL); 06. vii.1956, Batote, coll. G. Saran et al. 29757 (LWG); Ramban District: 25.vi.1955, Near Banihal tunnel slope, coll. Kaul and Party 23312 (LWG); 15.v.1954, eBanihal, 1,524m, coll. S.N. Singh et al. 10169 (LWG); Pulwama District: 22.vii.1956, between Mughal Maidan and Chatru, G. Saran et al. 30154 (LWG); Udhampur District: 15.v.1957, Kaul et al. 41597 (LWG); 20.xii.1986, Udhampur City, A. Swami 1046 (BSD); 13.iv.1987, Udhampur City, A. Swami 1154 (BSD); 31.iii.1987, Ramnagar, A. Swami 979 (BSD); 27.x.1963 Kud, G.S. Srivastava 86685 (LWG); 11.v.1954, near Tavi river, Ramnagar forest, J. Prasad 9966 (LWG). Madhya Pradesh: Chhindwara District: September 1914, Amarwara Range, coll. unknown, 10431 (DD); Dewas District: 24.ii.1988, Nadaej Dewas, coll. R.M. Paninuli 7156 (LWG); Dindori District: date unknown, S. Mandla, coll. unknown, 12572 (DD); Guna District: 26.i.1959, Chanderi, A. Singh et al. 55889 (LWG); Indore District: 11.ix.1986, Krishi Kshetra, Amrit Bagh, Kasturagram, coll. K.K. Khanna \& R. Saran 37579, 37577 (CAL); Jabalpur District: date unknown, coll. K.C. Hole 30150 (DD). Rewa District: 05.viii.1986, coll. R. Prasad 38162 (CAL); Sagar District: 26.viii.1913, Rahatgarh Reserve, coll. unknown, 12647 (DD); 12.iii.1913, Gourjhamar, coll. unknown, 12648 (DD); 26.viii.1913, Rahatgarh Reserve, coll. unknown,12647 (DD); Satna District: 31.xii.1958, small rock near Chithara station, coll. A. Singh et al. 54477 (LWG); Shivpuri District: 15.v.1988, Charch, coll. R.M. Painuli 7218 (LWG). Maharashtra: Dhule District: Dec. 1886, GBD s.n. (BSI); Nashik District: September, 1917, Igatpuri, coll. unknown, 25511 (BSI); October 1917, Church grounds, Igatpuri, coll. I. Almeida 25479 (BLAT); Solapur District: 30.vii.2011, Suinganapure Ghat, 700m, coll. K.U. Garad KUG 548 (LWG, MH). Odisha: Kalahandi District: 07.vi.1944, near Paudallamari, Kasipur, 792m, coll. H.F. Mooney 2544 (DD). Punjab: Bathinda District: 20.iii.1966, coll. N.C. Nair 36574 (BSD); Gurdaspur District: 02.vi.1928, Dhunera camp., coll. B. Ram 306 (DD); 24.viii.1969, Batala, coll. U.C. Bhattacharyya 39209 (BSD); 24.ii.1964, Batala, 247m, coll. Charanjeet 10902 (BSD); Hoshiarpur District: 24.viii.1977, Jaijon, coll. J.N. Vohra \& P. Daniel 60393 (BSD); 13.ix.1979, Tanda, P. Daniel 67348 (BSD); Jalandhar District: 21.iv.1972, Kotla, 
O.P. Misra 47147 (BSD); Nawanshahr District: 28. vii.1971, Manguwal, O.P. Misra 44681 (BSD). Rajasthan: Ajmer District: 07.iv.1954, Udaipur Marg, coll. Kaul et al., 8545 (LWG); 02.vi.1954, Bharatpur Road, coll. R. Singh 12826 (LWG); Banswara District: 29.viii.1976, Shargarh forest, 259m, coll. V. Singh 3091 (CAL); 27. iii.1977, Kushlgarh, coll. V. Singh 4289 (CAL); 29.viii.1976, Sargarh forest,259m, coll. Y. Singh 3091 (CAL); Bhilwara District: 03.x.1978, Shahpura, coll. A.N. Singh 5716 (CAL); 19.ii.1979, Nahar Sagar, coll. A.N. Singh 7173 (CAL); 03.x.1978, Shahpura, coll. A.N. Singh 5716 (CAL); Jaipur District: 25.v.2012, coll. T. Husain et al. s.n. (LWG); 01.i.2012, JVWU Garden, coll. P. Saxsena s.n. (LWG); Jhalawar District: 26.iv.1964, Aklora-Manoharthana, coll. D.M. Verma 3447 (CAL); Kota District: 10.xi.1969, Chhabra, V. Singh 91006 (LWG); Sirohi District: April, 1916, Rajputana, Mount Abu, coll. unknown, 25460 (BLAT); May, 1916, Gurushanker, Mount Abu, coll. unknown, A5 (BLAT); October, 1916, Oria, coll. unknown, 25462 (BLAT); October, 1918, Shergam, Mount Abu, coll. unknown, 25259 (BLAT); December, 1882, Rajaputana, 1,158m, coll. J.M. Woodrow s.n. (CAL); 14. iv.1960, Kodra Dam, Mount Abu, coll. S.K. Jain 62132 (BSI); 25.iv.1954, near Dilwara Temple, coll. Kaul et al., 9540 (LWG); Udaipur District: 12.iv.1914, Lansdowne Division, 1,524m, coll. G. Dutt Joshi 10904 (DD); 10.x.1962, Undabari Nul, coll. K.C. Kanodi, 82490 (BSI). Uttar Pradesh: Allahabad District: 29.viii.1963, Chatham, coll. R. Prasad 396 (CAL); Azamgarh District: 28.xi.1985, on road side of Ganj Road, Daulatabad, coll. Attar, 188 (BSD); Bahraich District: 12.iii.1964, Murtihagate, coll. G. Panigrahi \& O.P. Misra 2864 (CAL); 11.ii.1965, Bichhia, Nishangara, coll. O.P. Misra 7934 (CAL); 22.xi.1964, Gherua River, coll. G. Panigrahi 6566 (CAL); 08.iv.2009, Katerniaghat Barrier, coll. L.B. Chaudhary, A. Kumar \& O. Bajpai 250294 (LWG); 24.iv.2010, Near Bhainsa Lotan fata, Nishangara, Katerniaghat Wildlife Sanctuary, coll. A. Kumar \& O. Bajpai 252270 (LWG); 16.iii.2004, Karmohini Forest, coll. S.D. Maliya 225287 (LWG); 12. xi.2002, Nishangara forest, coll. S.D. Maliya 224632 (LWG); 23.viii.2002, Nishangara forest, coll. S.D. Maliya 223662 (LWG); 11.ii.1965, Bichhia, coll. O.P. Misra 7934 (CAL); 12.iii.1964, Murthiaghat, coll. G. Panigrahi \& O.P. Misra 2864 (CAL); 18.iii.2004, Kuthiyaghat forest, coll. S.D. Maliya 225906 (LWG); Balrampur District: 27. iv.1991, coll. K.K. Khanna 39977 (BSA); 05.xi.2011, M.L.K. (P.G.) College, coll. L.B. Chaudhary \& R. Tiwari 263777 (LWG); Bijnor District: 16.xi.1979, South to Dhampur towards Noorpur Road, coll. J.P. Sharma 70347 (BSD); Bulandshahar District: 10.v.1955, Nisurkha, coll. S.W. Devi s.n. (LWG); 23.iv.1963, Gulaoti, coll. N.P. Singh
27416 (BSD); 22.ii.1962, coll. N.P. Singh 19602 (BSD); Faizabad District: 05.vi.2013, Navodaya Vidhalaya, coll. R. Tiwari \& L.B. Chaudhary 264543 (LWG); Jhansi District: 28.xii.1954, four miles towards south, coll. Kaul et al. 17727 (LWG); Lakhimpur Kheri District: 18.iv.1956, Kukra, Bhira Forest, coll. G. Saran et al. 26424 (LWG); 23.iv.1956, Oel, coll. G. Saran et al. 26675 (LWG); 13. iv.1894, Bhira, Inayat 22775 (DD); 13.iv.1894, Inayat 22775a (CAL); 15.iii.1955, Chappartala, Gomti bank, coll. K. Ahmad, 19991 (LWG); Lucknow: 29.xi. 2010, Sultangang Police Station, Gokhale Marg, coll. R. Tiwari \& L.B. Chaudhary, 250375 (LWG); 19.i.2009, Kukrail Forest, coll. L.B. Chaudhary, A. Kumar \& O. Bajpai, 250178 (LWG); 11.v.2009, Gomti Nagar, coll. K.N. Nair, 250799 (LWG); 21.vii.2012, in front of Church, Aalambag, coll. L.B. Chaudhary, O. Bajpai \& R. Tiwari, 252783 (LWG); 21.vii. 2012, in front of Church, Aalambag, coll. L.B. Chaudhary, O. Bajpai \& R. Tiwari 252786 (LWG); in front of Church, Aalambag, 21.vii.2012, coll. L.B. Chaudhary, O. Bajpai \& R. Tiwari 252785 (LWG); in front of Church, Aalambag, 21.vii.2012, coll. L.B. Chaudhary, O. Bajpai \& R. Tiwari, 252784 (LWG); 21.vii.2012, in front of Church, Aalambag, coll. L.B. Chaudhary, O. Bajpai \& R. Tiwari, 252782 (LWG); 27.ix.2012, inside NBRI Guest House, coll. L.B. Chaudhary \& R. Tiwari, 264508 (LWG); 20.x.2012, in house garden, besides Police chauki, Gokhle Marg, coll. R. Tiwari \& L. B. Chaudhary, 264509 (LWG); 28.viii.2012, Way road in front of SBI, behind temple, coll. R. Tiwari \& L.B. Chaudhary, 264501 (LWG); 05.xii.2008, behind floriculture division, Botanic Garden, NBRI, coll. R.K. Srivastava \& A. Kumar, 249800 (LWG); 16.ii.2009, besides Dayal Fort, wall side of Polytechnic, coll. L.B. Chaudhary, 250252 (LWG); 27.iii.1955, Bot. Club I, Chinhat, 22079 (LWG); 12.vi.1958, coll. U. Shankar et al., 47124 (LWG); 18.iv.1957, Medicinal Plot, National Botanic Garden, coll. J.G. Srivastava s. n. (LWG); 06.i.1953, Sultanpur Road, coll. U. Shankar s. n. (LWG); 06.vi.1958, Moosa Bagh, Lucknow, coll. J.G. Srivastava et al., Hiralal, 46801, 24568 (LWG); 15.xii.1954, A.P. Sen Road, coll. J. Prasad, H. Lal \& A. Singh, 17432 (LWG); 02.vi.2013, Mahanagar, towards Wireless Chauraha, coll. L.B. Chaudhary \& A. Srivastava, 264547 (LWG); 08.v.1958, Mohanlalganj Forest, coll. J.G. Srivastava, 46996 (LWG); 18.ii.2011, coll. D. Iqbal s. n. (LWG); Mainpuri District: 16.xii.1998, Near Kundan Nagla on Kuraoli, coll. S.D. Maliya, 217056 (LWG); 28.x.1997, Rasemar, near Nanamau, coll. S.D. Maliya, 217028 (LWG); Moradabad District: 30.iv.1986, coll. M.L. Prasad 79953 (BSD); Pilibhit District: 28.viii.1972, Chuka head, Pilibhit, coll. C.L. Malhotra, 50539 (CAL); Rai Barelly District: 21.vi.1968, Compound of Chaudhary Saheb, 
coll. J. Asraf \& Aslam, 72027 (LWG); 11.v.1953, 10 10 mile, Rai Barelly Road, coll. U.S. Misra, s.n. (LWG); Varanasi District: 16.vii.1965, Kotwa, coll. O.P. Misra, 9722 (CAL). Uttarakhand: Almora District: 11.vi.1996, Mall Road, coll. D. Basu 76331 (BSD); 26.vi.1996, Almora City, coll. D. Basu 76400 (BSD); 16.x.1912, Dwarahat, coll. D. Hooper, 38922 (CAL); 13.vi.1996, Loharkhet, coll. D. Basu, 91709 (BSD); 15.ix.1912, 1,371m, coll. D. Hooper, 38922 (CAL); Bageshwar District: 24.ii.1955, 975m, coll. Kaul et al., 19274 (LWG); Chamoli District: date unknown, on way to Peng, coll. P.K. Hajra, 87332 (LWG); Deharadun District: coll. unknown, Bhilkia Range, Lansdowne Division, coll. J. Singh, 6084 (DD); 18.x.1989, Chakrata, coll. K.K. Singh et al., EBH 7928 (LWG); 28.v.1995, 2km from Tuini Town, Chakrata Road, coll. T.S. Rana et al., 219069 (LWG); 01.vi.1960, Chakrata Waterfall, coll. J.G. Srivastava et al., 78544 (LWG); 21.viii.1969, Road side 139/10, Rajaji Sanctuary, coll. J.V.S. Rao 38989 (BSD); 17.iv.1960, Rajpur, 914m, coll. H.M. Saxena, 533 (DD); 16.vii.1887, 488m, coll. U. Kanjilal s.n. (DD); 30.ix.1958, Tons Forest Division, Thadiar, coll. K.C. Sahni 27076 (DD); 15.vi.1902, 671m, coll. U. Kanjilal 1082 (DD); 30.v.1972, Teak Gate road, New Forest, coll. H.B. Naithani, 3576 (DD); 5.ix.1807, 1,829m, coll. unknown, 4044 (DD); 30.x.1960, Rajpur, 945m, coll. H.O. Saxena 1442 (DD); April 1937, coll. M.B. Raizada s.n. (DD); 6.xi.1921, Lachhiwala, coll. unknown, 104, (BSI); 17. vi.1955, Majra, coll. R.C. Bharadwaja et al., 6932 (LWG); 02.iv.1961, coll. M.A. Rau 14580 (BSD); 02.vii.1957, Rajpur, 1000m, coll. T.A. Rao, 3236 (BSD); 20.vii.1985, South of Yamuna River, Vikas Nagar, coll. J.P. Sharma, 77868 (BSD); 13.v.1994, F.R.R.N.P., Motichur, coll. K.K. Singh \& A. Prakash, 107817 (LWG); 21.vi.1982, Barami G.G. Valley, Tuli, coll. C.L. Malhotra, 51526 (BSD); date unknown, Jaunsar, W. R. 7882 (DD); 15.iv.1996, coll. Mohand, R. N.P., K.K. Singh \& A. Prakash 216344 (LWG); 22.x.1999, near Kalsi, 914m, coll. G. Awasthi, 257 (LWG); 27.iv.1993, Beriwada, F.R.R.N.P., coll. K.K. Singh \& A. Prakash, 212597 (LWG); 20.viii.1956, Haridwar road, coll. K.M. Balapure s. n. (DD); date unknown, Jaunsar, 1,829m, s. n. (DD); 19.xii.1956, Mussoorie, 2200m, coll. unknown, 1253 (BSD); 10.x.1960, Mussoorie, 1,676m, coll. H.O. Saxena, 1409 (DD); date unknown, Mussoorie, 1,829m, coll. H.O. Saxsena, 568 (DD); date unknown, Chakrata, coll. unknown, 25619 (BLAT); 26.vii.1985, Kulhal, coll. J.P. Sharma, 77908 (BSD); Kumaun District: 27.v.1979, Kafni, 2000m, coll. C.M. Arora, 66232 (BSD); 14.vi.1871, coll. G. King, s.n. (CAL); Nainital District: 26.x.2000, Mohan, Corbett Tiger Reserve, coll. H.C. Pande, 222094 (LWG); 26.iv.2000, Sandigaon, Corbett Tiger Reserve, coll. H.C. Pande, 220742 (LWG); 5.xi.1967, on the way of Naina Cheins Peak, coll. K.M. Balapure \& A. Pandey 81812 (LWG); 15.x.1987, Nandpuri, H. Singh 5794 (LWG); 20.vii.1910, 1,372m, coll. U. Dutt, 6044 (DD); 27.ii.1987, Gopalpuri, coll. H. Singh, EBH 5762 (LWG); 11.ii.1988, Himmatpur, Haldwani, coll. V. Singh, 466 (BSD); 24.v.1956, Haldwani, coll. Kapoor \& Jhamman 27756 (LWG); 23.ix.1989, Peepalsana Road, coll. H. Singh EBH 8016 (LWG); Date?, Bhima Range, 1,829m, S.D. Joshi, 29 (DD); 27.ii.87, Gopalpuri, coll. H. Singh, 5762 (LWG); 10.ii.1989, Barhani, coll. H. Singh EBH 7866 (LWG); 14.vi.1961, on the way to Nainital, coll. R. Rao 2912 (CAL); Pauri Garhwal District: 05.vii.1919, Dwarikhal, 1,310m, coll. A.E. Osmaston, 1099 (DD); 21. iv.1963, Agastyamuni, 900m, coll. C.L. Malhotra, 26828 (BSD); 15.vi.1971, Trisula, 1000m, coll. B.D. Naithani, 44238 (BSD); 03.vi.1975, Khirsa, 1800m, coll. B.S. Aswal, 55408 (BSD); 06.v.1995, Bhainswara, coll. B. P. Uniyal, 90593 (BSD); Pithoragarh District: 29.iv.1962, Madhkote, 1600m, coll. U.C. Bhattacharyya, 21333 (BSD); 19. iv.1984, Baram, coll. B. Balodi, 75627 (BSD); 11.v.1961, U. C. Bhattacharyya 15162 (BSD); 21.vi.1982, Tuli, G.G. Valley, coll. C.L. Malhotra, 51564 (BSD); 04.v.1965, Lilam, 1600m, coll. N.C. Nair, 35665 (BSD); Rudraprayag District: 20.iv.1963, coll. C.L. Malhotra 26813 (BSD); 1913, Ramnagar Division, Aduala Range, 792m, coll. H. Singh 7844 (DD); Tehri Garhwal District: 19.viii.1992, coll. B.P. Uniyal, 79485 (BSD); 08.vi.1959, Birehi Gohua, 1300m, coll. M.A. Rau, 10021 (CAL); 17.ii.1979, on east facing slopes, Tehri City, 640m, coll. A.K. Goel 64630 (BSD); Date?, Tehri Reserve Forest, coll. R.K. Gupta 34 (CAL); 09.vi.1972, Guthi, 1800m, coll. B.D. Naithani, 48208 (BSD); 8.vi.1959, 1300m, coll. M.A. Rao, 10021 (CAL); Udham Singh Nagar District: 21.ii.1955, Near Kichha, coll. Kaul et al. 18712 (LWG); 21.v.1955, Near Kichha, coll. Kaul et al. 19097 (LWG); Uttar Kashi District: 24.v.1995, between Mantad to Manoorkhad, Naitwar, coll. T.S. Rana et al. 218849 (LWG); 24.ix.1995, coll. S. Singh, 90117 (BSD); May, 1996, on the way of Istragad, coll. B. Balodi, 91503 (BSD); 24.v.1956, Bhatnagar 24769 (DD); 18.vi.1951, Gangnani, 1,371m, coll. D.D. Awasthi, 2421 (LWG). West Bengal: Howrah District: coll. unknown, Calcutta, Botanical Garden (HBC), coll. unknown, s.n. (CAL); date unknown, coll. S. Kurz, s.n. (CAL).

\section{REFERENCES}

Bamber, C.J. (1916). Plants of the Punjab. Lahore, xxviii+652pp.

Berg, C.C. (1989). Classification and Distribution of Ficus. Experiementia 45 (7): 605-611.

Berg, C.C. (2003). Flora Malesiana precursor for the treatment of 
Moraceae 1: The main subdivision of Ficus: The subgenera. Blumea 48: 167-178; http://dx.doi.org/10.3767/000651904X486278

Berg, C.C. (2004a). Flora Malesiana precursor for the treatment of Moraceae 6: Ficus subgenus Sycomorus. Blumea 49: 155-200; http://dx.doi.org/10.3767/000651904X484423

Berg, C.C. (2004b). Flora Malesiana precursor for the treatment of Moraceaea 7: Ficus subgenus Urostigma. Blumea 49: 463-480.

Berg, C.C. \& E.J.H. Corner (2005). Moraceae-Ficus. pp.1-730. In: Nooteboom, H. P. (ed.), Flora Malesiana, Series I (Seed Plants), 17 (2): National Herbarium Nederland, Universiteit Leiden branch, The Netherlands, iv+730pp.

Bhattacharyya, P.K. \& K. Sarkar (1998). Flora of West Champaran District, Bihar. Botanical Survey of India, Calcutta, 534pp.

Brandis, D. (1874). Forest Flora of North-West and Central India: A Handbook of the indigenous trees and shrubs of those countries. Wm. H. Allen and Co., London, xxxi +608pp.

Brandis, D. (1906). Indian Trees. An account of Trees, Shrubs, Woody climbers, Bamboos and Palms indigenous or commonly cultivated in the British Indian Empire. Archibald Constable and Company Ltd. London, xxiv+767 pp.

Browicz, K. (1982). Moraceae, pp. 1-8. In: Rechinger, K.H. (ed.), Flora Iranica. 153, Akademische Druck-U. Verlagsanstalt Graz-Austria, $15 \mathrm{pp}$.

Burrows, J. \& S. Burrows (2003). Figs of Southern and South-Central Africa. Umdaus Press, Hatfield, South Africa, viii+379pp.

Chaudhary, L.B., J.V. Sudhakar, A. Kumar, O. Bajpai, R. Tiwari \& G.V.S. Murthy (2012). Synopsis of the Genus Ficus L. (Moraceae) in India. Taiwania 57(2): 193-216.

Chowdhary, H.J. \& B.M. Wadhwa (1984). Flora of Himachal Pradesh Analysis, vol. 2. The Director, Botanical Survey of India, Howrah, 860pp.

Collett, H. (1902). Flora Simlensis, Thacker. Spink and Co.,Calcutta and Shimla, 652pp.

Corner, E.J.H. (1958). An Introduction to the distribution of Ficus Reinwardtia 4: 15-45.

Corner, E.J.H. (1965). Check List of Ficus in Asia and Australasia with keys to identification. Gardens Bulletin Singapore 21(1): 1-186.

Corner, E.J.H. (1981). Moraceae, pp. 230-279. In: Dassanayake, M.D. (eds.), A Revised Handbook to The Flora of Ceylon,(3) Oxford and IBH, New Delhi, India.

Dhaliwal, D.S. \& M. Sharma (1999). Flora of Kullu District. Bishen Singh Mahendra Pal Singh, Dehra Dun, 744pp.

Dixon, D.J. (2003). A taxonomic revision of the Australian Ficus species in the section Malvanthera (Ficus subg. Urostigma: Moraceae). Telopea 10 (1): 125-153.

Duthie, J.F. (1915). Flora of the Upper Gangetic Plain and of the Adjacent Siwalik and sub-Himalayan Tracts, vol. 3 (pt. 1) Superintendent Government Printing, Calcutta, India, 283pp.

Figweb (2004-2013). <http://www.figweb.org/Ficus/subgenus_ficus/ section ficus/subsection ficus/Ficus_palmata.htm>. Downloaded on 30 February 2013.

Gamble, J.S. (1921). Flora of the Presidency of Madras, Vol. 3 (By C.E.C. Fischer). Adlard and Son, Ltd. London, 1389pp.

Gaur, R.D. (1999). Flora of the District Garhwal North West Himalaya (Uttar Pradesh). Trans Media, Srinagar (Garhwal), 811pp.

Haines, H.H. (1924). The Botany of Bihar and Orissa. Pt. 5. Adlard and Son, London, ii+595pp.

Hajra, P.K. \& B. Balodi (1995). Plant Wealth of Nanda Devi Biosphere Reserve. Botanical Survey of India, Calcutta, 458pp.

Kader, S.A. (2009). Occurrence of Ficus palmata Forssk. subsp. virgata (Roxb.) Browicz in Kerala, south India - an addition to the flora of Kerala. Journal of Economic and Taxonomic Botany 33: 339-341.

Khanna, K.K. \& B.P. Uniyal (1997). Moraceae, pp. 607-625. In: Mudgal, V., K.K. Khanna \& P.K. Hajra (eds.), Flora of Madhya Pradesh - Vol. 2. Botanical Survey of India, Calcutta, 681pp.

Khanna, K.K., V. Mudgal, B.P. Uniyal \& J.R. Sharma (1999). Dicotyledonous plants of Uttar Pradesh, A Check-list. Bishen Singh Mahendra Pal Singh, Dehra Dun, 473pp.

King, G. (1887-1888). The Species of Ficus of the Indo-Malayan and
Chinese Countries. Annals of the Royal Botanic Garden, Calcutta, Vol.1 (parts 1 \& 2): 1-185 (+ i-xiii, i-vi, plates 1-232, 1-52, plates 1-5).

King, G. (1888). Ficus L., pp. 494-537. In: Hooker, J.D. (ed.). The Flora of British India - Volume 5. L. Reeve and Co., London, UK, 910pp.

Kirtikar, K.R. \& B.D. Basu (2001). Indian Medicinal Plants - 2nd Edition, Volume 10. Oriental Enterprises, Dehra Dun, xv+451pp.

Kochummen, K.M. (1998). New species and varieties of Moraceae from Malaysia. Gardens Bulletin Singapore 50(2): 197-219.

Kumar, A., O. Bajpai, A.K. Mishra, N. Sahu, S.K. Behera \& L.B. Chaudhary (2011). Assessment of diversity in the genus Ficus L. (Moraceae) of Katerniaghat Wildlife Sanctuary, Uttar Pradesh, India. American Journal of Plant Sciences 2: 78-92; http://dx.doi. org/10.4236/ajps.2011.21011

Kumar, S. (2001). Flora of Haryana. Bishen Singh and Mahendra Pal Singh, Dehra Dun, 507pp.

Maheshwari, J.K. (1963). The Flora of Delhi. CSIR, New Delhi, 447pp.

Matthew, K.M. (1999). The Flora of the Palni Hills, South India. Rapinat Herbarium, Tiruchirapalli, Pt. 2, pp. 576-1196.

Mooney, H. (1950). Supplement to the Botany of Bihar and Orissa. International Book Distributers, Dehra Dun, 294pp.

Nair, N.C. (1977). Flora of Bashahr Himalayas. International Bioscience Publishers, Haryana (India), 360pp.

Naithani, B.D. (1985). Flora of Chamoli - Volume 2. Botanical Survey of India, Howrah, pp. 381-800.

Osmaston, A.E. (1927). A Forest Flora for Kumaon. Bishen Singh Mahendra Pal Singh, Dehra Dun, 605pp.

Pandey, R.P. \& P. M. Padhye (2000). Wild relatives and related species of cultivated/crop plants and their diversity in Gujarat, India. Journal of Economic and Taxonomic Botany 24(2): 339-348.

Prain, D. (1903). Bengal Plants: A list of the phanerogams, fern and fern allies indigenous to, or commonly cultivated in the lower provinces and Chittagong, with definitions of the natural orders and genera, and key to the genera and species - Volume 2 (ApocynaceaeSelaginellaceae). Botanical Survey of India, Calcutta, 686pp.

Parker, R.N. (1918). Forest flora for Punjab with Hazara and New Delhi. Bishen Singh Mahendra Pal Singh, Dehra Dun (Reprint ed. 1973), xxxv+577pp

Parmar, C. \& M.K. Kaushal (1982). Ficus palmata. In Wild Fruits. Kalyani Publishers, New Delhi, India. pp.31-34. (http://www.hort. purdue.edu/newcrop/parmar/08.html).

Parmar, P.J., B.V. Shetty \& V. Singh (1991). Flora of Rajasthan, Flora of India, Series 2, Vol. 2. Botanical Survey of India, Calcutta, pp. 453-860.

Pullaiah, T. \& D.A. Maulali (1997). Flora of Andhra Pradesh (India) (Rubiaceae-Ceratophyllaceae) - Volume 2. Scientific Publishers, Jodhpur India, 456pp.

Rana, T.S., B. Datt \& R.R. Rao (2003). Flora of Tons Valley Garhwal Himalaya (Uttaranchal). Bishen Singh Mahendra Pal Singh, Dehra Dun, xvi+410pp.

Rao, G.V.S. \& G.R. Kumari (2008). Flora of Visakhapatnam District, Andhra Pradesh - Volume 2. Botanical Survey of India, Kolkata, 536pp.

Roxburgh, W. (1832). Flora Indica - Volume 3. Government Press, Serampore, $875 \mathrm{pp}$.

Roy, G.P., B.K. Shukla \& B. Datt (1992). Flora of Madhya Pradesh (Chhatarpur and Damoh). Ashish Publishing House, New Delhi, $639 p p$.

Saxena, H.O. \& M. Brahmam (1995). The Flora of Orissa - Volume 3. CSIR-Regional Laboratory and Orissa Forest Development Ltd., Bhubaneswar, 685 pp.

Shah, G.L. (1978). Flora of Gujarat State (part 2). Sardar Patel University, Vallabh Vidyanagar, iv+471pp.

Sharma, B.M. \& P. Kachroo (1981). Flora of Jammu and plants of Neighbourhood - Volume 1. Bishen Singh Mahendra Pal Singh, Dehra Dun, 407pp.

Sharma, J.K. \& J.S. Dhakre (1995). Flora of Agra District. Botanical Survey of India, Calcutta, 356pp.

Sharma, M. (1990). Punjab Plants: Check-list. Bishen Singh Mahendra 
Pal Singh, Dehra Dun, 115pp.

Sharma, N. (2002). The Flora of Rajasthan. Aaviskar Publisher, Distributors, Jaipur, India, 280pp.

Singh, D. \& M. Sharma (1999). Flora of Kullu District, Himacha Pradesh. Bishen Singh Mahendra Pal Singh, Dehra Dun, 744pp.

Singh, K.K. \& A. Prakash (2002). Flora of Rajaji National Park Uttaranchal. Bishen Singh Mahendra Pal Singh, Dehra Dun, $x+275 p p$.

Singh, M.P. (1986). Flora of Patna: Dicotyledons. International Books and Periodicals Supply Service, New Delhi, 343pp.

Singh, N.P., P. Lakshminarasimhan, S. Karthikeyan \& P.V. Prasanna (2001a). Flora of Maharashtra state, Dicotyledons - Volume 2. Flora of India, Series 2. Botanical Survey of India, Kolkata, 1080pp.

Singh, N.P., V. Mudgal, K.K. Khanna, S.C. Srivastava, A.K. Sahoo, S Bandyopadhyay, N. Aziz, M. Das, R.P. Bhattacharya \& P.K. Hajra (2001b). Flora of Bihar - Analysis. Botanical Survey of India, Calcutta, $777 \mathrm{pp}$

Singh, S.K. \& G.S. Rawat (2000). Flora of Great Himalayan National Park, Himachal Pradesh. Bishen Singh Mahendra Pal Singh, Dehra Dun, 304pp.
Singh, V. (1983). Flora of Banswara, Rajasthan, Flora of India, Series 3. Botanical Survey of India, Howrah, 312pp.

Srivastava, T.N. (1976). Flora Gorakhpurensis. Today and Tomorrow Printers and Publishers, New Delhi, 411pp.

Stewart, J.L. (1869). Punjab Plants: Comprising Botanical and Vernacular Names, and Uses of Most of the Trees, Shrubs, and Herbs of Economical Value, Growing Within the Province. Govt. Press, Lahore, 375pp.

Stewart, J.L. \& D. Brandis (1874). The Forest Flora of North-West and Central India. Bishen Singh Mahendra Pal Singh, Dehra Dun, xxxi+608pp.

Swami, A. \& B.K. Gupta (1998). Flora of Udhampur. Bishen Singh Mahendra Pal Singh. Dehra Dun, 455pp.

Verma, D.M., P.C. Pant \& M.I. Hanfi (1985). Flora of Raipur, Durg and Rajnandgaon. Flora of India Series 3. Botanical Survey of India, Howrah, 524pp.

Wu, Z., Z.K. Zhou \& M.G. Gilber (2003). Moraceae, pp. 21-73. In: Wu. Z., P.H. Raven \& D.Y. Hong (eds.). Flora of China, vol. 5. Science Press, Beijing, and Missouri Botanical Garden Press, St. Louis, 506pp. 